\title{
Growth hormone modulates IL- $\alpha$ and IFN- $\gamma$ release by murine splenocytes activated by LPS or porins of Salmonella Typhimurium
}

\author{
L. SOMMESE, G. DONNARUMMA, G. CIPOLLARO DE L'ERO, A. MARCATILI, M. VITIELLO and \\ M. GALDIERO*
}

Istituto di Microbiologia, Facoltà di Medicina e Chirurgia, Seconda Università degli Studi di Napoli, Larghetto S. Aniello a Caponapoli, 2-80138 Napoli and *Dipartimento di Patologia, Profilassi ed Ispezione degli Alimenti, Sezione di Malattie Infettive, Facoltà di Veterinaria, Università degli Studi di Napoli, Federico II, Italy

\begin{abstract}
The effect of growth hormone (GH) on the release of IL-1 $\alpha$ and IFN- $\gamma$ from murine splenocytes was investigated. Their release from splenocytes activated by Salmonella enterica serovar Typhimurium lipopolysaccharide (LPS) $0.5 \mu \mathrm{g} / \mathrm{ml}$ was increased by c. $65 \%$ in the presence of $\mathbf{G H} 100 \mathrm{pg} / \mathrm{ml}$. With splenocytes activated by $S$. Typhimurium porins $5 \mu \mathrm{g} / \mathrm{ml}$, GH increased the production of both IL-1 $\alpha$ and IFN- $\gamma$ by $c .56 \%$. Polymyxin treatment abolished the cytokine-releasing activity of LPS but had no effect on the activity of the porin preparation.
\end{abstract}

\section{Introduction}

The potential physiological role of growth hormone $(\mathrm{GH})$ in immunoregulation has been demonstrated by Edwards et al. [1]. GH has recently been shown to be synthesised locally, by lymphoid cells in regional lymph nodes [2]. GH, as prolactin (PRL), is a member of the group 1 cytokine family, all of which have an antiparallel 4- $\alpha$-helical bundle structure [3]. Both LPS and outer-membrane proteins, such as porins, of gramnegative bacteria can stimulate cells involved in the immune response to release cytokines [4] and LPS is known to be a potent stimulus of GH release [5].

The immune response is controlled at several levels. Considerable work has recently been focused on lymphocyte expression of receptors at various stages of the lymphocyte lifespan. Both thymocytes [6] and human lymphocyte cell lines [7] have detectable and saturable specific cell-surface receptors for $\mathrm{GH}$. Whether or not the receptor for $\mathrm{GH}$ is present at certain times in the cell cycle has not yet been clarified, but $\mathrm{GH}$ could act as an additional signal in the functional specialisation of lymphocytes, providing an opportunity for immune intervention. Besides being an external signal, GH could also act at different levels of internal signal transmission in order to activate DNA transcription.

In the present study, the release of IL- $1 \alpha$ and IFN- $\gamma$ by murine splenocytes stimulated with $\mathrm{GH}$ and with

Received 19 June 1995; revised version accepted 11 Dec. 1995. Corresponding author: Dr L. Sommese. two components of the outer membrane of gramnegative bacteria - LPS and porins-was investigated.

\section{Materials and methods}

Animals

BALB/cByJ male mice weighing 20-22 g were used. The animals were housed at constant temperature $\left(20 \pm 2^{\circ} \mathrm{C}\right)$ under a fixed 12-h light-dark cycle with free access to food (Mignini $70 \mathrm{~K}$ standard diet) and water.

\section{Reagents}

Growth hormone (GH) from porcine pituitary glands and polymyxin B were purchased from Sigma. The presence of endotoxin in reagents was checked by the Limulus amoebocyte lysate test [8] and all results were negative (i.e., $<0.05 \mathrm{EU}$ of $\mathrm{LPS} / \mathrm{ml}$ of sample).

\section{Preparation of porins and LPS}

Salmonella enterica serovar Typhimurium strain SH5014 [9], kindly provided by Dr M. Nurminen (National Public Health Institute, Helsinki, Finland) was used as a source of the porins [10]. Briefly, $1 \mathrm{~g}$ (wet wt) of cell envelopes was suspended in Triton $\mathrm{X}$ $1002 \% \mathrm{v} / \mathrm{v}$ in $0.01 \mathrm{M}$ Tris- $\mathrm{HCl}, \mathrm{pH} 7.5$, containing $10 \mathrm{mM}$ EDTA; after the addition of trypsin $(10 \mathrm{mg} / \mathrm{g}$ of envelopes), the pellet was dissolved in sodium dodecyl sulphate (SDS) buffer (SDS $4 \% \mathrm{w} / \mathrm{v}$ in $0.1 \mathrm{M}$ sodium phosphate, $\mathrm{pH}$ 7.2) and applied to an Ultragel AcA34 column equilibrated with SDS $(0.25 \% \mathrm{w} / \mathrm{v})$ buffer. The 
fraction containing proteins, identified by absorbance at $280 \mathrm{~nm}$, was dialysed extensively and examined by SDS-PAGE by the method of Laemmli [11]. The protein content of the porin preparation was determined by the method of Lowry et al. [12].

LPS was isolated from $S$. Typhimurium SH5014 by the phenol-chloroform-ether method of Galanos et al. [13].

\section{Polymyxin treatment}

The LPS activity in the porins was neutralised by adding a 1:10 (w:w) ratio of protein:polymyxin $\mathrm{B}$ and incubating at room temperature for $1 \mathrm{~h}$. LPS was mixed with polymyxin B at a 1:100 (w:w) ratio (LPS:polymyxin B) [14]. LPS, porins and the mixtures containing polymyxin $B$ were used in pyrogen-free phosphatebuffered saline (PBS), unless otherwise specified.

\section{Assays with murine splenocytes}

Splenocytes were prepared according to conventional procedures from aseptically removed mouse spleens. The cells were washed three times in RPMI 1640 medium (Labtek Laboratories, Eurobio, Paris, France) and resuspended in complete RPMI medium (RPMI supplemented with fetal calf serum $10 \% \mathrm{v} / \mathrm{v}, 2 \mathrm{mM}$ glutamine, $10 \mathrm{mM}$ HEPES, penicillin $100 \mathrm{U} / \mathrm{ml}$, streptomycin $100 \mu \mathrm{g} / \mathrm{ml}$ ) at a final concentration of $3 \times 10^{6}$ cells $/ \mathrm{ml}$. Cell viability was evaluated by the trypan blue exclusion test. LPS or porins and GH, in RPMI 1640 medium, were added to the culture at the concentrations indicated in each assay. After $24 \mathrm{~h}$, cell viability was checked and the culture supernates were collected and stored at $-20^{\circ} \mathrm{C}$ until assayed for cytokines. Pilot studies had shown that $24 \mathrm{~h}$ was the average cytokine secretion time (data not shown).

\section{RNA isolation and cDNA preparation}

Splenocytes $\left(1 \times 10^{7}\right)$, cultured in complete RPMI medium under different experimental conditions, were collected after $5 \mathrm{~h}$ and total RNA was extracted by the method of Chomczynski and Sacchi [15].

The RNA pellet was resuspended in ethanol $75 \% \mathrm{v} / \mathrm{v}$, sedimented, vacuum-dried and dissolved in $15 \mu \mathrm{l}$ of RNAase-free water. One $\mu \mathrm{g}$ of oligo (dT) (Promega Biotec, Madison, WI, USA) was added to the suspension and the mixture was heated at $65^{\circ} \mathrm{C}$ for 5 min. After cooling on ice, the mixture was incubated for $2 \mathrm{~h}$ at $42^{\circ} \mathrm{C}$ with $14 \mu \mathrm{l}$ of the following mixture: $20 \mathrm{mM}$ dithiothreitol (Sigma); $1 \mathrm{mM}$ (each) dATP, dGTP, dCTP and dTTP; RNasin (Promega) $35 \mathrm{U}$ and Moloney murine leukemia virus reverse transcriptase (Gibco BRL Life Technologies, Eggenstein, Germany) $525 \mathrm{U}$ in reverse transcription buffer.

\section{PCR procedure}

PCR primers for murine $\beta$ actin, interleukin $1 \alpha$ (IL$1 \alpha)$, and interferon- $\gamma$ (IFN- $\gamma$ ) were purchased from Clontech (Palo Alto, CA, USA). cDNA $(2 \mu 1)$ prepared as described above was amplified in the presence of $500 \mathrm{nM}$ (final concentration) $5^{\prime}$ and $3^{\prime}$ primers, $200 \mu \mathrm{M}$ (each) dATP, dGTP, dCTP, dTTP and Taq DNA polymerase (Promega) $1.25 \mathrm{U}$ made up to a final volume of $50 \mu \mathrm{l}$ with Taq DNA polymerase $10 \times$ buffer (Promega). The PCR was performed in a Perkin-Elmer thermal cycler for 30 cycles as follows: denaturation, $1 \mathrm{~min}$ at $94^{\circ} \mathrm{C}$; annealing, $2 \mathrm{~min}$ at $60^{\circ} \mathrm{C}$ and extension, $3 \mathrm{~min}$ at $72^{\circ} \mathrm{C}$. The reaction products were visualised by electrophoresis of $25 \mu 1$ of the reaction mixture at $100 \mathrm{~V}$ in an agarose $1.5 \%$ gel containing ethidium bromide $1 \mu \mathrm{g} / \mathrm{ml}$. The gels were then examined on an $\mathrm{UV}$ light box and photographed. One $\mu \mathrm{g}$ of $B g l \mathrm{I}-$ and

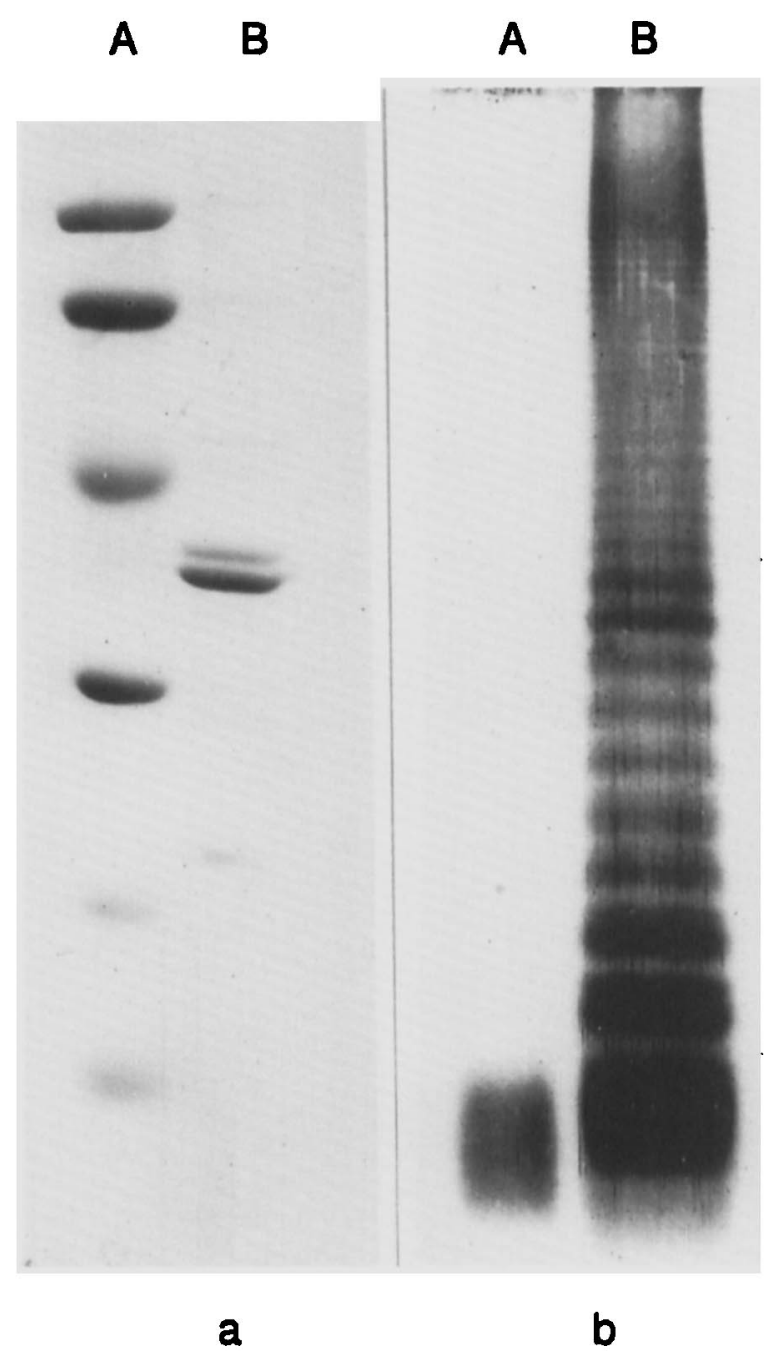

Fig. 1. SDS-PAGE analysis of porins and LPS preparations from S. Typhimurium SH5014. a, lane A, mol.wt standards (phosphorylase b, 94000 ; albumin, 67000; ovoalbumin, 43000 ; carbonic anydrase, 30000 ; trypsin inhibitor, $20100 ; \alpha$-lactalbumin, 14000 ); B, SH5014 porins. b, lane A, SH5014 LPS; B, S. Typhimurium smooth LPS (Difco). 
Hin fl-digested pBR328 DNA (Boehringer Mannheim) was run in parallel as mol. wt markers (providing bands at 2176, 1766, 1230, 1033, 653, 517, 453, 394, 298, 234, 220 and $154 \mathrm{bp}$ ).

\section{Cytokine assays}

All measurements were performed with monoclonal antibodies. IL- $1 \alpha$ was measured with a Mouse Interleukin- $1 \alpha$ ELISA kit (Genzyme Corporation Cambridge, MA, USA); IFN- $\gamma$ was measured with a Mouse Interferon- $\gamma$ ELISA kit (Genzyme).

\section{Statistical analysis}

All experiments were performed in triplicate; results were expressed as the mean and SD. Comparisons between tests were by Student's $t$ test, with statistical significance considered to be $\mathrm{p}<0.05$.

\section{Results}

\section{Porin and LPS preparations}

The composition of the porin preparation, as examined by SDS-PAGE, is shown in Fig. 1a. Two polypeptides, of 34 and $36 \mathrm{kDa}$, were the main components. The LPS concentration in the porin preparation was estimated to be c. $0.005 \%$ by weight of the protein.

The profile of the LPS preparation, as revealed by SDS-PAGE and staining with silver nitrate [16], showed that the LPS was in the R phase (Fig. 1b).

\section{Cytokine release by splenocytes stimulated with LPS and GH}

The release of IL- $1 \alpha$ and IFN- $\gamma$ from splenocytes $\left(3 \times 10^{6} / \mathrm{ml}\right)$ incubated with different concentrations of LPS with and without GH $100 \mathrm{pg} / \mathrm{ml}$ are shown in Fig. 2. With LPS $0.5 \mu \mathrm{g} / \mathrm{ml}$ alone, splenocytes released

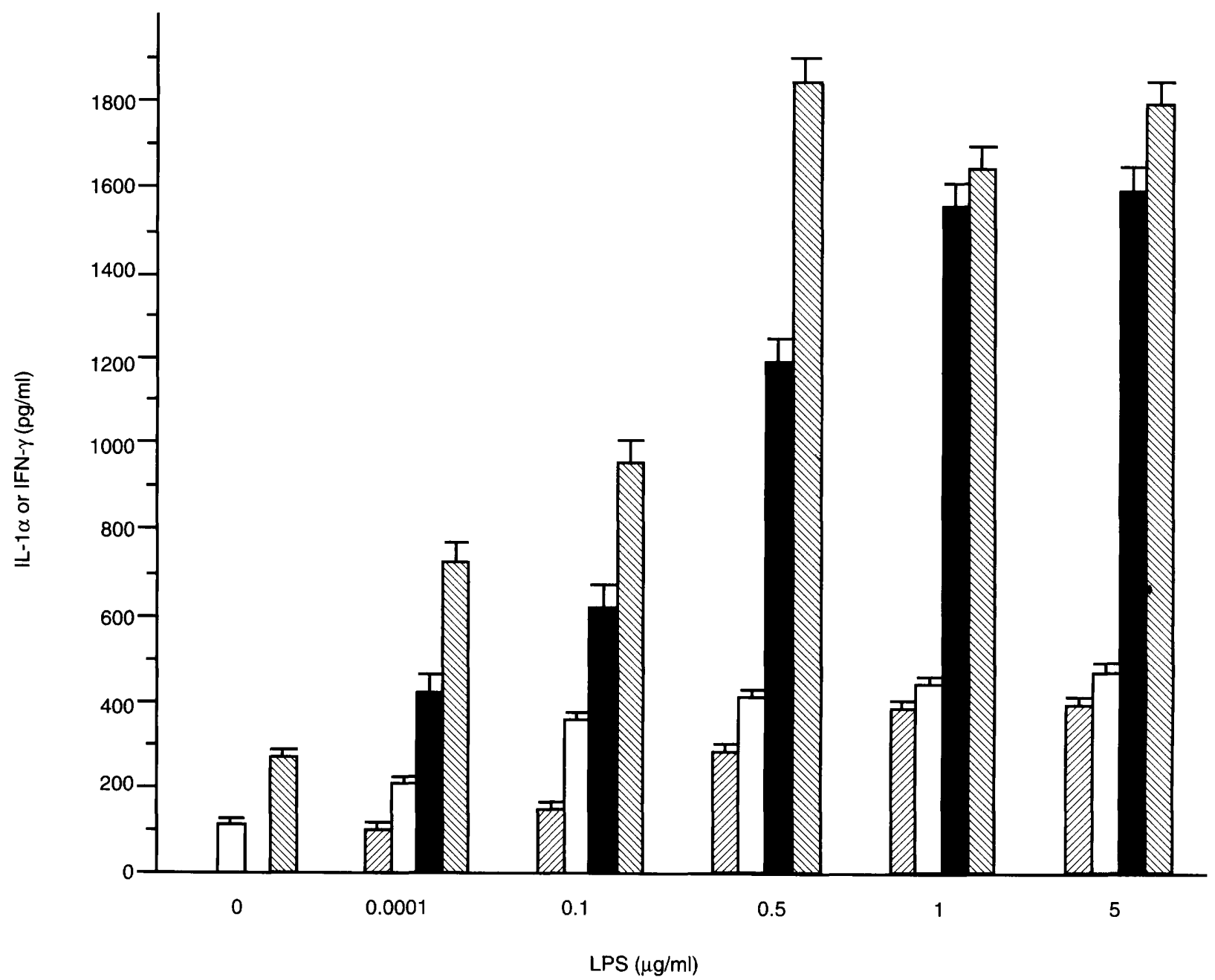

Fig. 2. Effect of GH $100 \mathrm{pg} / \mathrm{ml}$ on production of IL-1 $\alpha$ and IFN- $\gamma$ by murine splenocytes stimulated with different amounts of LPS $(0-5 \mu \mathrm{g} / \mathrm{ml})$ : $\square$, IL- $1 \alpha$ production in the absence of $\mathrm{GH} ; \square$, IL- $1 \alpha$ production in the presence of GH $100 \mathrm{pg} / \mathrm{ml} ; \mathbf{\square}$, IFN- $\gamma$ production in the absence of GH; $\mathbb{N}, \mathrm{IFN}-\gamma$ production in the presence of GH $100 \mathrm{pg} / \mathrm{ml}$. Each column represents the mean of three determinations and the bars indicate SD. 
285 SD $18 \mathrm{pg}$ of IL- $1 \alpha / \mathrm{ml}$ and $1200 \mathrm{SD} 60 \mathrm{pg}$ of IFN$\gamma / \mathrm{ml}$ into the supernate. With GH and LPS $0.5 \mu \mathrm{g} / \mathrm{ml}$, splenocytes released $415 \mathrm{SD} 20 \mathrm{pg}$ of IL- $\alpha / \mathrm{ml}$ and $1846 \mathrm{SD} 60 \mathrm{pg}$ of IFN $-\gamma / \mathrm{ml}$ into the supernate. With $\mathrm{GH}$ and concentrations of LPS $\leqslant 0.5 \mu \mathrm{g} / \mathrm{ml}$, cytokine release was greater than the sum of the amounts released by GH and LPS alone. With LPS concentrations $>0.5 \mu \mathrm{g} / \mathrm{ml}$, the release was less than the sum of the amounts released by either stimulus alone. GH alone, without prior stimulus with LPS, had only weak cytokine-releasing activity. Controls without LPS and GH did not release significant amounts of cytokines (data not shown). Splenocytes stimulated with LPS mixed with polymyxin B (LPS:polymyxin B 1:100 w:w) did not release significant amounts of cytokines and polymyxin $\mathrm{B}$ alone, at the concentration used in the LPS mixture, gave no significant stimulation of cytokine release (data not shown).

With a fixed amount of LPS $(0.5 \mu \mathrm{g} / \mathrm{ml})$ and different concentrations of $\mathrm{GH}(10,100$ and $1000 \mathrm{pg} / \mathrm{ml})$, it was seen that both IL- $1 \alpha$ and IFN- $\gamma$ release were greatest at a $\mathrm{GH}$ concentration of $100 \mathrm{pg} / \mathrm{ml}$ (Fig. 3).

\section{Cytokine release by splenocytes stimulated with porins and $\mathrm{GH}$}

The release of IL- $1 \alpha$ and IFN- $\gamma$ from splenocytes $\left(3 \times 10^{6} / \mathrm{ml}\right)$ incubated with different concentrations of porins with and without $\mathrm{GH} 100 \mathrm{pg} / \mathrm{ml}$ are shown in Fig. 4. With porins $5 \mu \mathrm{g} / \mathrm{ml}$, splenocytes released $120 \mathrm{SD} 10 \mathrm{pg}$ of IL- $1 \alpha / \mathrm{ml}$ and $600 \mathrm{SD} 25 \mathrm{pg}$ of IFN$\gamma / \mathrm{ml}$ into the supernate. With $\mathrm{GH}$ and porins $5 \mu \mathrm{g} / \mathrm{ml}$, splenocytes released $257 \mathrm{SD} 10 \mathrm{pg}$ of $\mathrm{IL}-1 \alpha / \mathrm{ml}$ and $936 \mathrm{SD} 25 \mathrm{pg}$ of IFN $-\gamma / \mathrm{ml}$ into the supernate. With GH and porin concentrations $\leqslant 5 \mu \mathrm{g} / \mathrm{ml}$, cytokine release was greater than the sum of the amounts released by $\mathrm{GH}$ and porins alone. With a porin concentration of $10 \mu \mathrm{g} / \mathrm{ml}$, the release was less than the sum of the amounts released by either stimulus alone. Again, GH alone, without prior stimulus with porins, had only weak cytokine-releasing activity. Controls without porins and GH did not release significant amounts of cytokines (data not shown).

Splenocytes treated with porin mixed with polymyxin B (porin:polymyxin B, 1:10, w:w) to neutralise the

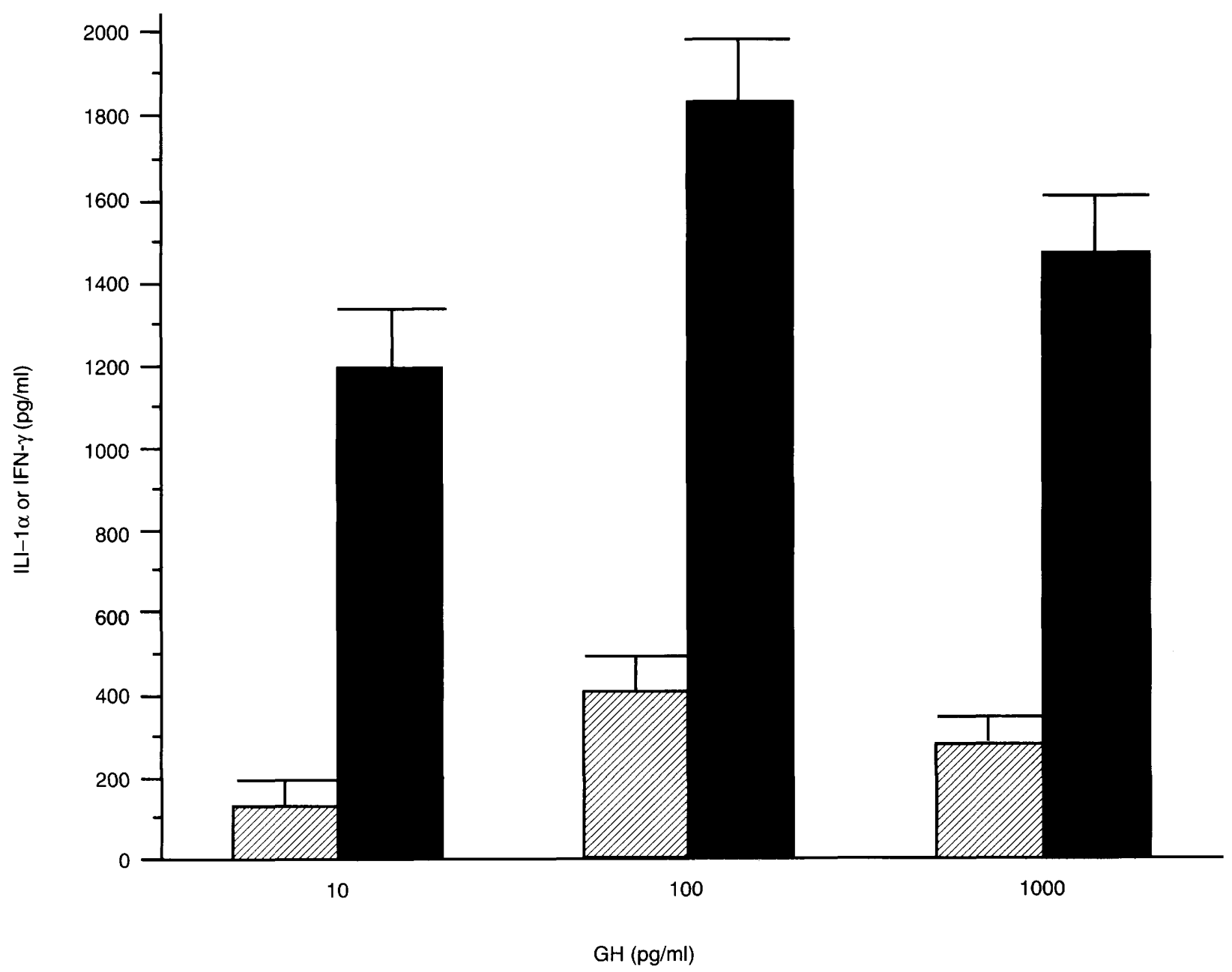

Fig. 3. Release of IL- $1 \alpha$ and IFN- $\gamma$ from murine splenocytes stimulated with LPS $0.5 \mu \mathrm{g} / \mathrm{ml}$ and various amounts of $\mathrm{GH}(10,100,1000 \mathrm{pg} / \mathrm{ml}): \llbracket, \mathrm{IL}-1 \alpha$ production in the presence of $\mathrm{GH} ; \mathbf{\square}$, IFN- $\gamma$ production in the presence of GH. Each column represents the mean of three determinations and the bars indicate SD. 


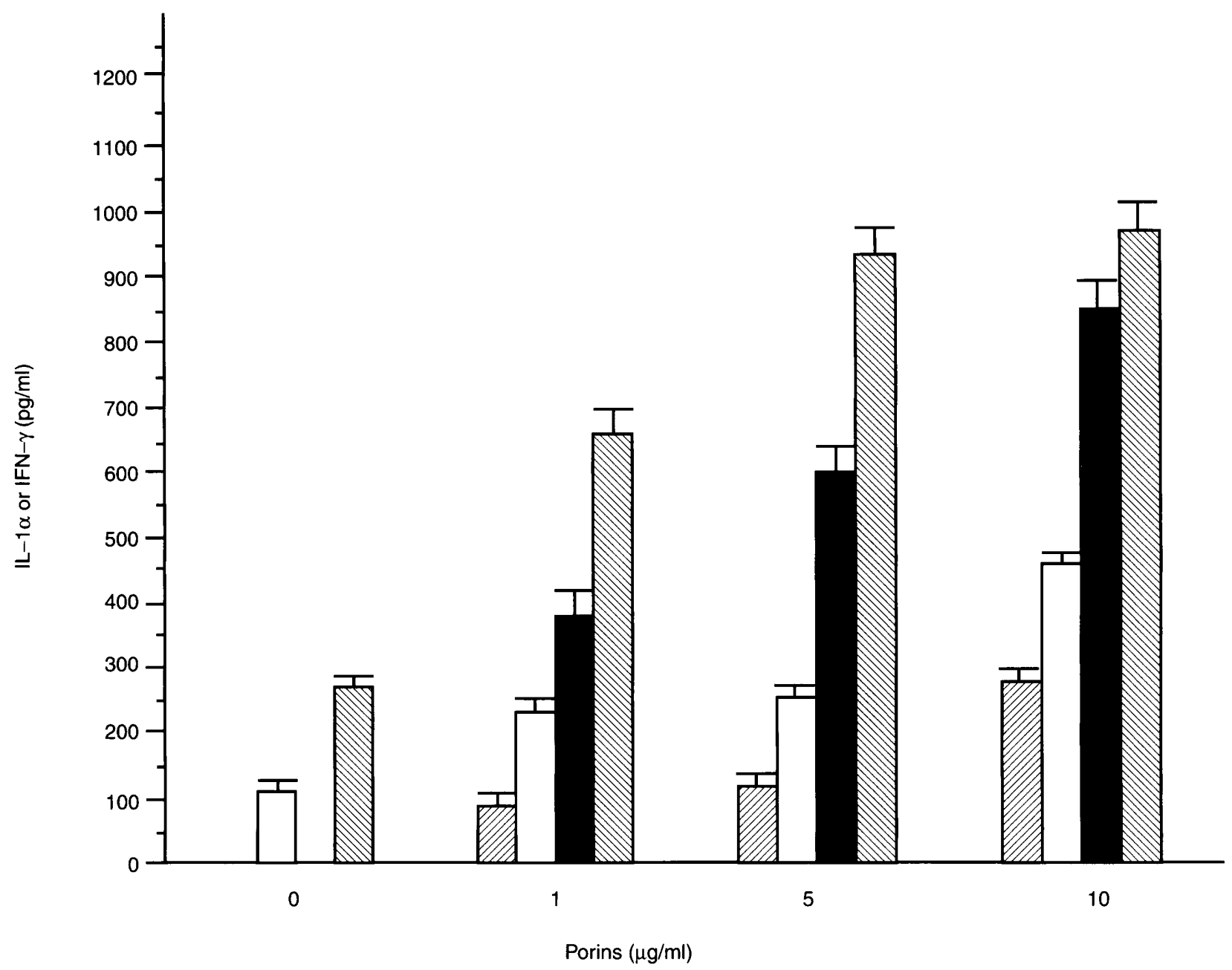

Fig. 4. Effect of GH $100 \mathrm{pg} / \mathrm{ml}$ on production of IL- $1 \alpha$ and IFN- $\gamma$ by murine splenocytes stimulated with different amounts of porins $(0-10 \mu \mathrm{g} / \mathrm{ml})$ : 四, IL- $1 \alpha$ production in the absence of $\mathrm{GH} ; \square$. IL- $1 \alpha$ production in the presence of

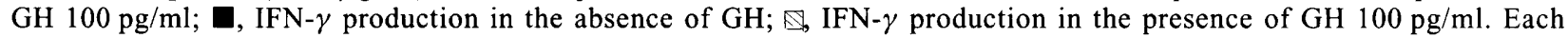
column represents the mean of three determinations and the bars indicate SD.

effect of small amounts of LPS in the porin preparation, showed the same results as porins alone (data not shown). This showed that the effect was due to porins and not to LPS. Polymyxin B alone, at the concentration used in the porin mixture, gave no significant stimulation of cytokine release (data not shown).

With a fixed concentration of porins $(5 \mu \mathrm{g} / \mathrm{ml})$ and different concentrations of $\mathrm{GH}(10,100$ and $1000 \mathrm{pg} /$ $\mathrm{ml}$ ) it was seen that both IL- $1 \alpha$ and IFN- $\gamma$ release was greatest at a GH concentration of $100 \mathrm{pg} / \mathrm{ml}$ (Fig. 5).

\section{Patterns of cytokine mRNA expression in cultured splenocytes}

The data on the release of IL- $1 \alpha$ and IFN- $\gamma$ in the supernates were confirmed by studies on specific mRNA in cells treated in the same manner.

The effect of $\mathrm{GH} 100 \mathrm{pg} / \mathrm{ml}$ on cytokine mRNA expression in splenocytes stimulated with LPS $0.5 \mu \mathrm{g} /$ $\mathrm{ml}$ and porins $5 \mu \mathrm{g} / \mathrm{ml}$ is shown in Fig. 6. The intensity of the mRNA bands for IL- $1 \alpha$ and IFN- $\gamma$ in splenocytes stimulated with either LPS or porins was increased after treatment with $\mathrm{GH}$ under the same experimental conditions. IL- $\alpha$ and IFN- $\gamma$ mRNAs were detected only at low levels in splenocytes cultured with $\mathrm{GH}$ alone.

\section{Discussion}

Bidirectional communication signals occur in the neuroendocrine-immune system interactions. They are important in host resistance to infectious, autoimmune and neoplastic diseases [17]. The concept that GH affects cells of the immune system is demonstrated by the requirement for $\mathrm{GH}$ in order to maintain lymphatic tissues populated with lymphocytes, as removal of this hormone results in atrophy of the thymus and secondary lymphoid tissues [18-21]. It has been well established that the immune system has evolved a very elaborate process for the internal regulation of 


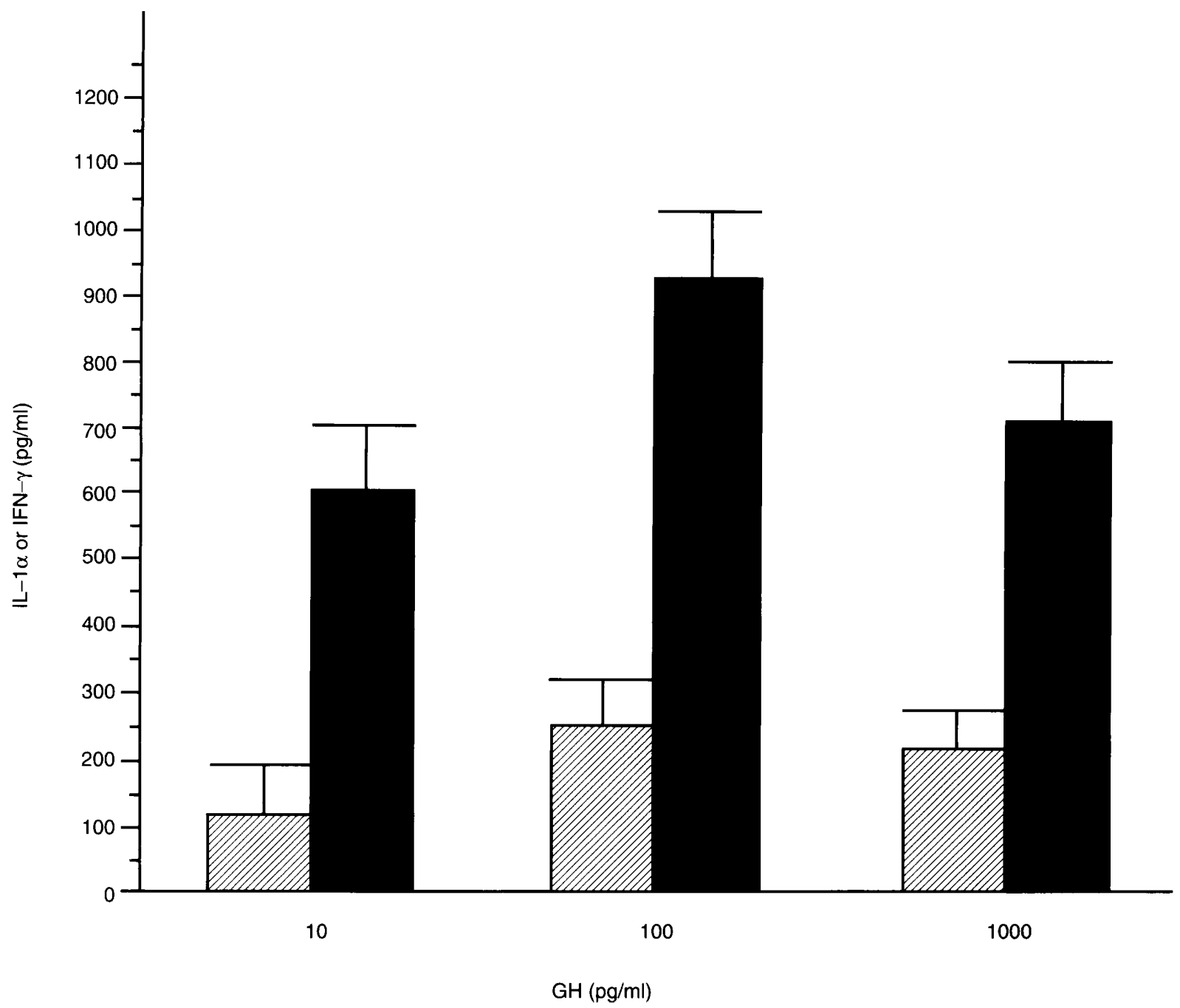

Fig. 5. Release of IL- $1 \alpha$ and IFN- $\gamma$ from murine splenocytes stimulated with porins $5 \mu \mathrm{g} / \mathrm{ml}$ and various amounts of $\mathrm{GH}(10,100,1000 \mathrm{pg} / \mathrm{ml})$ : $\mathbb{Z}, \mathrm{IL}-1 \alpha$ production in the presence of $\mathrm{GH} ; \boldsymbol{\mathbf { a }}$, IFN- $\gamma$ production in the presence of GH. Each column represents the mean of three determinations and the bars indicate SD.

lymphocyte growth and differentiation; this process involves the release of soluble mediators and the timely appearance of cell-surface receptors specific for these mediators at discrete points during the cell cycle of activated lymphocytes $[22,23]$.

LPS and porins are surface components of gramnegative bacteria that greatly activate cells involved in the immune response. Activated cells possess the ability to produce a large variety of cytokines; these cytokines can trigger other cell types involved in immune responses.

The data show the remarkable role of $\mathrm{GH}$ in regulating the release of IL- $1 \alpha$ and IFN- $\gamma$ in cells after their stimulation by porins or LPS. GH, at an optimal concentration which probably varies from cell type to cell type, can regulate cytokine release in relation to the intensity of the stimulus to which the cell has been exposed. In the present study, with low levels of LPS or porins cytokine release was enhanced when $\mathrm{GH}$ was present. In contrast, at higher concentrations of LPS or porins, cytokine release in the presence of $\mathrm{GH}$ was usually less than the sum of the levels released by either agent alone. The effect of $\mathrm{GH}$ on cytokine release from cells stimulated with these bacterial components was confirmed by studies on specific mRNA expression.

The effect of GH on IL- $1 \alpha$ and IFN- $\gamma$ release and on other cytokines probably involves a series of changes in target cells involved in the immune response. The ability of GH to modulate cytokine release induced by LPS or porins may be correlated with its role in cell metabolism. Raima and Holtta [24] have reported that GH stimulated ornithine decarboxylase (ODC) activity in the isolated perfused rat liver. Kay and Cooke [25] and Klinpel et al. [26] observed a marked increase in ODC activity after stimulation of human lymphocytes with various mitogenic lectins. The activity of ODC rises during the early stages of growth in many eukaryotic cells and has been reported to have an unusually short half-life [27]. Enhanced cellular expression of ODC causes an increase in cellular 


\section{$\begin{array}{lllllll}1 & 2 & 3 & 4 & 5 & 6 & 7\end{array}$}

IL-1 $\alpha$

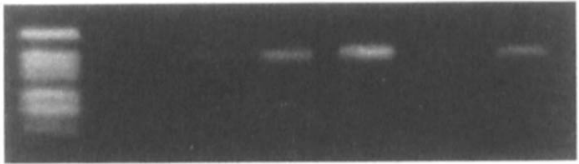

IFN- $\gamma$

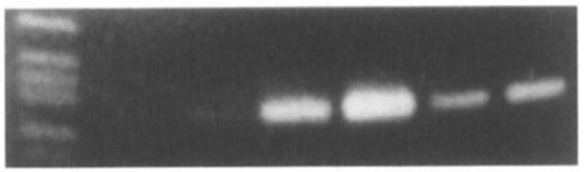

$\beta$-actin

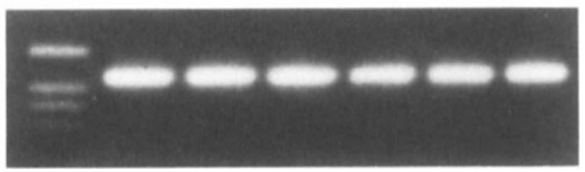

Fig. 6. Effect of GH on cytokine mRNA expression in splenocytes cultured alone (lane 2) or in the presence of GH (3), LPS (4), LPS + GH (5), porins (6) and porins $+\mathrm{GH}$ (7). After $5 \mathrm{~h}$, RNA was extracted and reverse transcribed. The cDNAs obtained were assayed for the presence of specific cytokine mRNA by PCR as described in Materials and methods. Reaction products were run on agarose $1.5 \%$ gels in the presence of appropriate mol.wt markers (lane 1). $\beta$-Actin was the positive control for transcription.

levels of polyamines [28]; these cationic molecules have been implicated as vital co-factors involved in protein, RNA and DNA synthesis.

Regulation of cytokine synthesis occurs at different transcriptional and post-transcriptional levels [29-31] and a modulatory effect, either directly or indirectly, by $\mathrm{GH}$ can occur at either level [17-32]. GH can play a supportive role during the complex series of events that occur during lymphocyte activation by enhancing the uptake of key nutrients, by raising the level of intermediary cellular metabolism, and through the maintenance of high levels of protein synthesis. Presumably $\mathrm{GH}$ provides mechanisms that offer another level of cytokine regulation to protect the host. It has been shown that $\mathrm{GH}$ is required for protection against the lethal effects of $S$. Typhimurium [33]. The consequences of inflammatory pathway activation during disease are often the result of synergic toxicity between cytokines. The potential pathophysiological role of $\mathrm{GH}$ in immunoregulation has been demonstrated by several lines of evidence. GH has been shown to be synthesised locally by lymphoid cells [2]. LPS is a potent stimulus of GH secretion [5] and also of IL-1. In vivo, IL-1 causes the release of $\mathrm{GH}$ [34]. These findings suggest that the process of infection or inflammation and consequent immune activation can affect neuroendocrine function.

It has also been shown that other hormones may counteract the biological activity of cytokines. Mela- nocyte-stimulating hormone attenuates the development of inflammatory acute phase responses induced by tumor necrosis factor (TNF) or IL-1 [35]. Glucocorticoid hormones increase the survival of animals given otherwise lethal doses of IL-1 or TNF [36]. These data suggest that the endocrine system may modulate cytokine secretion by preventing the undesired toxic effects resulting from cytokine excess or favouring cytokine activity at low concentrations.

\section{References}

1. Edwards CK, Ghiassudin SM, Schepper JM, Yunger LM, Kelley KW. A newly defined property of somatotropin: priming of macrophages for production of superoxide anion. Science 1988; 239: 769-771.

2. Weigent DA, Baxter JB, Wear WE, Smith LR, Bost KL, Blalock JE. Production of immunoreactive growth hormone by mononuclear leukocytes. FASEB J 1988; 2: 2812-2818.

3. Abdel-Meguid SS, Shieh H-S, Smith WW, Dayringer HE, Violand BN, Bentle LA. Three-dimensional structure of a genetically engineered variant of porcine growth hormone. Proc Natl Acad Sci USA 1987; 84: 6434-6437.

4. Galdiero F, Cipollaro de l'Ero G, Benedetto N, Galdiero M, Tufano MA. Release of cytokines induced by Salmonella typhimurium porins. Infect Immun 1993; 61: 155-161.

5. Frohman LA, Horton ES, Lebovitz HE. Growth hormone releasing action of a Pseudomonas endotoxin (piromen). Metabolism 1967; 16: 57-67.

6. Arrembrecht S. Specific binding of growth hormone to thymocytes. Nature 1974; 252: 255-257.

7. Leisniak MA, Gordon P, Roth J, Gavin JR. Binding of ${ }^{125} \mathrm{I}$ human growth hormone to specific receptors in human cultured lymphocytes. J Biol Chem 1974; 249: 1661-1667.

8. Yin ET, Galanos C, Kinsky S et al. Picogram-sensitive assay for endotoxin: gelation of Limulus polyphemus blood cell lysate induced by purified lipopolysaccharide and lipid A from Gram-negative bacteria. Biochim Biophys Acta 1972; 261: $284-289$.

9. Nurminen M, Lounatmaa K, Sarvas M, Makela PH, Nakae T. Bacteriophage-resistant mutants of Salmonella typhimurium deficient in two major outer membrane proteins. $J$ Bacteriol 1976; 127: 941-955.

10. Nurminen $M$. Isolation of porin trimers. In: Korhonen TK, Dawes EA, Makela PM (eds) Enterobacterial surface antigens methods for molecular characterization. FEMS 1985; Symposium 25. Amsterdam: Elsevier Science Publishers BV, 1985: 294-299.

11. Laemmli UK. Cleavage of structural proteins during the assembly of the head of the bacteriophage T4. Nature 1970; 227: $680-685$.

12. Lowry $\mathrm{OH}$, Rosebrough NJ, Farr AL, Randall RJ. Protein measurement with Folin phenol reagent. J Biol Chem 1951; 193: $265-275$.

13. Galanos C, Luderitz O, Westphal O. A new method for the extraction of R lipopolysaccharides. Eur J Biochem 1969; 9: $245-249$.

14. Rifkind D. Prevention by polymixin B of endotoxin lethality in mice. J Bacteriol 1967; 93: 1463-1464.

15. Chomczynski P, Sacchi N. Single-step method of RNA isolation by acid guainidinium thiocyanate-phenol-chloroform extraction. Anal Biochem 1987; 162: 156-159.

16. Tsai C-M, Frasch CE. A sensitive silver stain for detecting lipopolysaccharides in polyacrylamide gels. Anal Biochem 1982; 119: 115-119.

17. Blalock JE. A molecular basis for bidirectional communication between the immune and neuroendocrine systems. Physiol Rev 1989; 69: $1-32$.

18. Baroni $C$. Thymus, peripheral lymphoid tissues and immunological responsiveness of the pituitary dwarf mouse. Experientia 1967; 23: 282-283.

19. Bianchi E, Pierpaoli W, Sorkin E. Cytological changes in the mouse anterior pituitary after neonatal thymectomy: a light and electron microscopical study. $J$ Endocrinol 1971; 51: 1-9. 
20. Pierpaoli W, Sorkin E. Cellular modifications in the hypophysis of neonatally thymectomized mice. BrJ Exp Pathol 1967; 48: 627-631.

21. Pierpaoli W, Sorkin E. Hormones and immunologic capacity. I. Effect of heterologous anti-growth hormone (ASTH) antiserum on thymus and peripheral lymphatic tissue in mice. Induction of a wasting syndrome. $J$ Immunol 1968; 101: 1036-1043.

22. Eshet R, Manheimer S, Chobsieng P, Laron Z. Human growth hormone receptors in human circulating lymphocytes. Horm Metab Res 1975; 7: 352-353.

23. Kiess W, Butenandt O. Specific growth hormone receptors on human peripheral mononuclear cells: reexpression, identification, and characterization. J Clin Endocrinol Metab 1985; 60 740-746.

24. Raina A, Holtta E. The effect of growth hormone on the synthesis and accumulation of polyamines in mammalian tissue. In: Pecile A and Muller EE (eds) Growth and growth hormone, Proceedings of the 2nd International Symposium on Growth Hormones, Milan. Amsterdam, Excerpta Medica 1972: $143-145$.

25. Kay JE, Cooke A. Ornithine decarboxylase and ribosomal RNA synthesis during the stimulation of lymphocytes by phytohemagglutinin. FEBS 1971; 16: 9-12.

26. Klimpel GR, Byus CV, Russell DH, Lucas DO. Cyclic AMPdependent protein kinase activation and the induction of ornithine decarboxylase during lymphocyte mitogenesis. $J$ Immunol 1979; 123: 817-824.

27. Russell DH, Snyder SH. Amine synthesis in regenerating rat liver: extremely rapid turnover of ornithine decarboxylase. $\mathrm{Mol}$ Pharmacol 1969; 5: 253-262.

28. Fillingame RH, Jorstad CM, Morris DR. Increased cellular levels of spermidine or spermine are required for optimal DNA synthesis in lymphocytes activated by concanavalin A. Proc
Natl Acad Sci USA 1975; 72: 4042-4045.

29. Turner M, Chantry D, Buchan G, Barrett K, Feldmann M Regulation of expression of human IL- $\alpha$ and $\mathrm{IL}-1 \beta$ genes. $J$ Immunol 1989; 143: 3556-3561.

30. Arend WP, D'Angelo S, Joslin FG. Regulation of interleukin 1 production in human monocytes. 1. Effects of gammainterferon and cycloheximide. Clin Exp Immunol 1988; 74: 377-381.

31. Arend WP, Gordon DF, Wood WM, Janson RW, Joslin FG, Jameel S. IL- $\beta$ production in cultured human monocytes is regulated at multiple levels. $J$ Immunol 1989; 143: 118-126.

32. Doglio A, Dani C, Grimaldi P, Ailhaud G. Growth hormone stimulates c-fos gene expression by means of protein kinase $\mathrm{C}$ without increasing inositol lipid turnover. Proc Natl Acad Sci USA 1989; 86: 1148-1152.

33. Edwards CK, Yunger LM, Lorence RM, Dantzer R, Kelley $\mathrm{KW}$. The pituitary gland is required for protection against lethal effects of Salmonella typhimurium. Proc Natl Acad Sci USA 1991; 88: 2274-2277.

34. Rettori V, Jurcovicova J, McCann SM. Central action of interleukin-1 in altering the release of TSH, growth hormone, and prolactin in the male rat. $J$ Neurosci Res 1987; 18: 179183.

35. Robertson B, Dostal K, Daynes RA. Neuropeptide regulation of inflammatory and immunologic responses. The capacity of alpha-melanocyte-stimulating hormone to inhibit tumor necrosis factor and IL-1-inducible biologic responses. J Immunol 1988; 140: 4300-4307.

36. Zuckerman S, Shellhaas J, Butler LD. Differential regulation of lipopolysaccharide-induced interleukin 1 and tumor necrosis factor synthesis: effects of endogenous and exogenous glucocorticoids and the role of the pituitary-adrenal axis. Eur J Immunol 1989; 19: 301-305. 